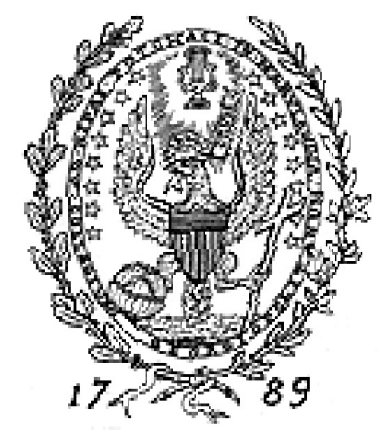

Bioethics Research Library

The Joseph and Rose Kennedy Institute of Ethics

Box 571212, Georgetown University

Washington, DC 20057-1212

202-687-3885; fax: 202-687-8089

bioethics@georgetown.edu

http://bioethics.georgetown.edu

\title{
Incentives for Providing Organs
}

\section{Patricia Milmoe McCarrick \\ Martina Darragh}

March, 2003

After a contentious debate at its 2002 annual meeting, the American Medical Association's House of Delegates voted to endorse the opinion of its Council on Ethical and Judicial Affairs that the impact of financial incentives on organ donation should be studied (Josefson 2002). The shortage of organs for transplantation has been an ongoing problem for more than 20 years. In June 1981, Representative Philip Crane (R-IL) introduced legislation in the U.S. House of Representatives proposing a $\$ 25,000$ income tax deduction and a $\$ 25,000$ estate tax exclusion for donating an organ (Tax Incentives 1981). Still the National Organ Transplant Act enacted in October 1984 prohibited the offering of any "valuable consideration" in return for organs (United States 1984).

The developments of a legal market for tissues in the United States and a black market for organs around the world have raised the question of whether donation without compensation is the only ethically viable option. Some critics of the current system claim reliance on donation actually promotes a black market in organs (Kaserman and Barnett 2002, p. 38; Palmer 1999, p. 36). In addition, a new set of compensation issues has arisen as living kidney donor transplantations begin to rival those performed with cadaveric organs (United States 2001).

As a result, current suggestions for incentives go far beyond the traditional death benefit payment to include such ideas as medals of honor for donors, reimbursement for funeral expenses, exchange programs for organ donation, and special medical insurance for living organ donors. Numerous bills introduced into the 107th Congress have proposed such incentives (Delmonico et al. 2002.) In October 2002, the U.S. Department of Health and Human Services awarded $\$ 5.2$ million in grants to study both clinical and behavioral interventions for increasing organ donations that do no

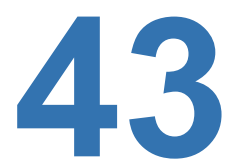


involve incentives. The inspiration for some of the funded proposals comes from the successes of Spain's social services and the United Kingdom's clinical administration of organ procurement programs (Robeznieks 2002).

With a nod to evidence-based medicine, the underlying concern expressed in much of the current literature is that no idea for increasing the supply of organs should be discounted before it is studied. This bibliography provides a short introduction to the range of opinions expressed on the issue of incentives for providing organs.

al-Mousawi, M.; Samhan, M.; al-Mezairee I.; Razzak, M.A.; and Khawari, F. Cadaver Organ Procurement in Kuwait. Transplantation Proceedings 31 (8): 3375-76, 1999.

The authors describe a protocol that significantly increased cadaveric organ donation and credit it with fostering the expansion of an organ sharing program among the Arab Gulf states. Developed by Kuwaiti neurologists and anesthetists after a continuing education course on transplantation, the protocol places a special emphasis on the role of local transplant coordinators who facilitate the investigation of brain death cases by neurologists.

Arnold, Robert; Bartlett, Steven; Bernat, James; et al. [Ethics Committee of the American Society of Transplant Surgeons] Financial Incentives for Cadaver Organ Donation: an Ethical Reappraisal. Transplantation 73 (8): 1361-67, 27 April 2002.

To prepare for proposed studies of financial incentives for organ donation, the American Society of Transplant Surgeons convened a panel to develop a methodology for evaluating the ethics of such research. Comprised of organ procurement organization executives, physicians, surgeons, and ethicists, the panel generated a list of nine criteria for use in judging any incentives proposal. While opposed to direct payment or tax incentives for organ donation, a majority of the members support funeral expense reimbursement or charitable contributions as incentives that would not violate or undermine the ideal of altruism.

Cameron, J. Stewart, and Hoffenberg, Raymond. The Ethics of Organ Transplantation Reconsidered: Paid Organ Donation and the Use of Executed Prisoners as Donors. Kidney International 55 (2): 724-32, February 1999.

After reviewing arguments for and against payment for organ procurement, the authors apply these arguments to the specific case of obtaining organs from executed prisoners. Holding that "[t]he affront to human dignity and autonomy is not the removal of organs after execution, but the execution itself," the authors go on to ask "... what the balance of harm may be between death of an individual in renal failure and the obtaining of a kidney from an individual already dead by due legal process" ( $p$. 730).

Cohen, Cynthia B. Public Policy and the Sale of Human Organs. Kennedy Institute of Ethics Journal 12 (1): 47-64, March 2002.

Responding to an article by Gill and Sade in the same issue, Cohen refutes their claim that selling a kidney and selling blood are comparable situations and suggests that they have confused Kant's notions of motive ("an end given by reason alone") and incentive ("an end based on empirical desires") in their reframing of Kant's philosophy to support payment for organs.

Cohen, Lloyd R. Increasing the Supply of Transplant Organs: The Virtues of a Futures Market. George Washington Law Review 58 (1): 1-51, November 1989.

Cohen proposes to alleviate the shortage in transplantable organs through a futures market in which individuals sign contracts to sell their organs after death. The author holds that his proposal would not exploit the poor because it is limited to cadaveric organs, and it would not favor the rich because allocation of the harvested organs would be done by a government or voluntary agency, not a 
corporation.

Daar, Abdallah S. Paid Organ Donation-The

Grey Basket Concept. Journal of Medical Ethics 24 (6): 365-68, December 1998.

Calling a ban on paid organ donation "hypocrisy" in a society based on rugged individualism where a substantial percentage of the population has no health insurance, the author reviews instances where religious and secular scholars support financial incentives for organ donors. Calling Sweden's incentives program for living donors an "ethically acceptable model," Daar goes on to wonder whether ". . . the ethical litmus test is not whether the giver is a vendor or donor, but whether the physician is a profiteer or healer" (p. 367).

Daar, Abdallah S. Rewarded Gifting. Transplantation Proceedings 24 (5): 2207-11, October 1992.

To clarify the role of incentives for organ donation and to distinguish them from "rampant commercialism," Daar provides a history of the term "rewarded gifting," traces its conceptual development through presentations at professional society meetings and international congresses, and reviews the arguments for and against such incentives.

Delmonico, Francis L.; Arnold, Robert; Scheper-Hughes, Nancy; et al. Ethical Incentives-Not Payment-for Organ Donation. New England Journal of Medicine 346 (25): 2002-5, 20 June 2002.

After noting that living donor transplantations have surpassed those performed with cadaveric organs at many U.S. transplantation centers, the authors propose incentives other than direct payments that would encourage both cadaveric organ donation-e.g., donor medals of honor and reimbursement for funeral expenses - and living donation - e.g., medical leave and special donor insurance. This article also contains a review of recent amendments to the National Organ Transplant Act introduced in the 107th
Congress.

Dossetor, John B. Rewarded Gifting: Is it Ever Ethically Acceptable? Transplantation Proceedings 24 (5): 2092-94, October 1992.

After stating that he would purchase a kidney from ". . . any approved ethical and legal source," the author finds that religious, legal, and professional ethics are inadequate for constructing a system in which he could do so. Instead, Dossetor draws on Tristram Engelhardt's notion of "moral strangers" to analyze the issue of kidney sales, and describes "indirect altruism," an aspect of rewarded gifting in which some form of compensation enables a person to act altruistically toward a third party.

Fentiman, Linda C. Organ Donation as National Service: A Proposed Federal Organ Donation Law. Suffolk University Law Review 27 (4): 1593-1612, Winter 1993.

After lamenting the fact that legislative attempts to increase organ donation have failed, Fentiman states that "[w]e must view organ donation as an act of community service, and support it in the way that we currently encourage service in a volunteer military or the Peace Corps, with the provision of subsidized education, health, and other benefits to those who serve" (p. 1598).

Fox, Renée C., and Swazey, Judith P. Spare Parts: Organ Replacement in American Society. New York: Oxford University Press, 1992. 254 p. Fox and Swazey critically review the acceleration of organ transplantation in the United States during the 1980s and early 1990 s and find "especially disturbing" ". . the 'spare parts' pragmatism" thereof (p.xv). The authors discuss sociologist Marcel Mauss's gift-exchange paradigm in relation to organ donation and track the alterations to this paradigm introduced over time. After a discussion of transplantation issues and the "medical commons"-_"medical care as a common ground that contains a finite amount of resources"(p. 73) - the second half of the book 
is devoted to the history of the Jarvik-7 artificial heart.

Freeman, Richard B. U.S. Viewpoint. Liver Transplantation 6 (4): 503-6, July 2000.

Freeman compares and contrasts organ donation systems in the United States and in Spain (the "Spanish model") where the latter ". . . has shown us that an extremely organized system with local emphasis, national coordination, and professionalism at every level is essential for improving organ donation rates" (p. 506). The author goes on to caution that the Spanish model would not necessarily be as successful in countries with different health care delivery systems or ethical standards.

Ghods, A. J.; Ossareh, S.; and Khosravani, P. Comparison of Some Socioeconomic Characteristics of Donors and Recipients in a Controlled Living Unrelated Donor Renal Transplantation Program. Transplantation Proceedings 33 (5): 2626-27, August 2001.

Due to the cultural and religious objections to cadaveric organ donation, the expense of end-stage renal disease programs, and the large number of patients receiving transplants outside the country at government expense, a living unrelated donor (LUD) program for renal transplantation was begun in Iran in 1988. The authors describe the organization and administration of this program and provide a statistical profile of those who have participated in it.

Gill, Michael B., and Sade, Robert M. Paying for Kidneys: The Case Against Prohibition. Kennedy Institute of Ethics Journal 12 (1): 17-45, March 2002.

After making the distinction between receiving payment for an organ versus buying an organ, Gill and Sade hold that an autonomous individual has a right to be paid for organ donation. They respond to objections that such a system would prey on the poor by stating that exploitation "can be addressed adequately only by attending to large-scale real-world societal conditions, not by looking at isolated hypothetical cases." Stating that "... there is no good reason to think that selling a kidney violates even the robust Kantian sense of autonomy," the authors proclaim "... my kidney is not my humanity. Humanity - what gives us dignity and intrinsic value - is our ability to make rational decisions, and a person can continue to make rational decisions with only one kidney."

Goyal, Madhav; Mehta, Ravindra L.; Schneiderman, Lawrence J.; and Sehgal, Ashwini

R. Economic and Health Consequences of Selling a Kidney in India. JAMA 288 (13): 1589-93, 2 October 2002.

The authors studied the health and economic consequences of paid kidney donation in India where the practice is widespread among the poor despite a legal ban. They found that "[s]elling a kidney did not lead to a long-term economic benefit for the seller and was associated with a decline in health status" and hold that their findings ". . . undercut five key assumptions made by supporters of the sale of kidneys."

Hansmann, Henry. The Economics and Ethics of Markets for Human Organs. Journal of Health Politics, Policy and Law 14 (1): 57-85, Spring 1989.

After identifying the shortage of transplantable organs as a problem of supply and demand that only a market economy can solve, Hansmann proceeds to describe the possible organization and regulation of such markets. Admitting that "[i]t would be foolish to suggest that the market offers a magic solution to the many agonizingly difficult issues involved in organ transplantation," Hansmann nevertheless holds that ". . . given the disabilities of the current system for obtaining and allocating organs and the improvements that are at least potentially available by permitting appropriate forms of compensation, the present blanket prohibition on any form of payment seems extreme" (pp. 83-84). 
Harris, John, and Erin, Charles. An Ethically Defensible Market in Organs: A Single Buyer Like the NHS [National Health Service] Is an Answer [Editorial]. BMJ 325 (7356): 114-15, 20 July 2002.

The authors review their proposal to structure a system of monetary incentives for organ donation as a monopsony (where only one buyer exists for the products of several sellers) to protect vulnerable populations and to promote social justice concerns. The authors discuss granting organ donors special status on allocation lists, exempting donor fees from taxation, and avoiding conflicts of interest when setting prices.

Hinkle, Whitney. Giving Until It Hurts: Prisoners Are Not the Answer to the National Organ Shortage. Indiana Law Review 35 (2): 593-619, 2002.

Hinkle criticizes the proposal that organs be obtained from executed prisoners and extends her critique to the suggestion that living organ donation can become a means to reducing jail time.

Joralemon, Donald. Shifting Ethics: Debating the Incentive Question in Organ Transplantation. Journal of Medical Ethics 27 (1): 30-35, February 2001.

The author traces how the arguments for and against paid organ donation have changed over the years, both in the medical community and in the general public, and applauds the caution with which financial incentives are approached.

Josefson, Deborah. AMA [American Medical Association] Considers Whether to Pay for Donation of Organs [News]. BMJ 324 (7353): 1541, 29 June 2002.

After a heated debate at their June 2002 annual meeting, the AMA's House of Delegates voted to accept its Council for Ethical and Judicial Affairs December 2001 recommendation that further study of financial incentives for organ donation was warranted.
Kaserman, David L., and Barnett, A. H. Alternative Policy Proposals: A Survey and Comparative Economic Analysis. In their The U.S. Organ Procurement System: A Prescription for Reform, pp. 41-68. Washington, DC: AEI (American Enterprise Institute) Press, 2002.

Decrying the inertia that results from a piecemeal approach to policy reform, the authors review alternative organ procurement policies including express donation, presumed consent, conscription, routine request, compensation, and organ markets. They describe an organ market as a distinct alternative from a system of fixed compensation, which would not be as responsive to supply and demand or as efficient with available organs. "For the first time, both the profit carrot and the competition stick would be brought to bear on the organ acquisition process" (p. 54). The chapter concludes with a social welfare analysis of each procurement alternative.

Matas, Arthur J. Ethical Incentives-Not Payment-For Organ Donation [Correspondence]. New England Journal of Medicine 347 (17): 1382-84, 24 October 2002.

Responding to the article by Delmonico et al., the author contends that a market for procuring organs from the living would not necessarily result in the brokering of organs if a government program based on fixed fees for organs and a predetermined algorithm for allocation were to be established.

Miller Ronald B. Ethics of Paid Organ Donation and the Use of Executed Prisoners as Donors: A Dialectic with Professors Cameron and Hoffenberg. Kidney International 55 (2): 733-37, February 1999.

Believing the essay by Cameron and Hoffenberg to be "... an important contribution in no small measure because its views are unconventional" (p. 734), Miller suggests that "[a] well-planned study of financial incentives to transplantation would be ethical even if it failed to increase organ donation, since we would then know that we should not introduce such a public policy"(p. 
736). The author concludes the article by wondering whether, "... if there were a societal policy favoring presumed consent for organ donation at death, ... it could be ethically presumed for prisoners as well as for other citizens" (p. 737).

Murray, Thomas H. Organ Vendors, Families, and the Gift of Life. In Organ Transplantation: Meanings and Realities, ed. Stuart J. Youngner, Renée C. Fox; and Laurence J. O'Connell, pp. 101-25. Madison: University of Wisconsin Press, 1996.

The author examines three proposals for organ recovery that involve some form of compensation: Lloyd R. Cohen's futures market, Henry Hansmann's health insurance premium credits, and Thomas G. Peters' death benefit payment to families for cadaver organs. Murray cautions that to refer to the providers of organs in any of these proposals as "donors" is "[c]onfusion in language ... [that] encourages conceptual confusion," which in turn can lead to faulty analysis of other factors contributing to the organ shortage (p. 108). Describing the "market analysis of organ recovery [as] seductive because it . . . evokes many of our culture's values and assumptions ... [including] a view of markets as fair and efficient institutions for producing and distributing goods" (p. 114), the chapter concludes with an overview of Renée C. Fox and Judith P. Swazey's alternative perspective on markets and organs.

Olbourne, Norman A. Ethical Considerations Underpinning the Donation of Live, Non-Regenerative Organs. Journal of Law and Medicine 9 (1): 76-79, August 2001.

Noting that individuals have proprietary rights over their regenerative tissues, Olbourne holds that "the ethical grounds are weak for denying an individual the right to dispose of a kidney (or any other non-regenerative organ) in any way he or she sees fit." As long as the informed consent process for the donor is rigorous, the author proclaims that "[i]t is ethically unsound for the community to intercede ... [and] there are sound ethical grounds for allowing the 'market to rule!"' (p. 79).

Palmer, Louis J., Jr. Organ Transplants from Executed Prisoners: An Argument for the Creation of Death Sentence Organ Removal Statutes. Jefferson, NC: McFarland, 1999. 156 p. In support of his proposition that organ procurement be considered a part of capital punishment, Palmer reviews English common law as it applies to the rights of a corpse and compares donation-based and futures-market organ supply systems.

Peters, Thomas G. Life or Death: The Issue of Payment in Cadaveric Organ Donation (Commentary.) JAMA 265 (10): 1302-5, 13 March 1991.

Based on his experience as a transplantation surgeon, the author states that "[w]e who have advocated 'free choice' in altruistic organ donation have fully ignored the fact that we are imposing our own values on persons who may not appreciate those values at all." Peters proposes that a death benefit payment be made to families for cadaveric organ donation, and reviews the arguments for and against such a practice.

Peters, Thomas G. A Stand in Favor of Financial Incentives in Organ Recovery [Guest Editorial]. Dialysis \& Transplantation 31 (5): 322, 324-25, May 2002.

Decrying the media's sensationalism in their coverage of proposed financial incentives for organ donation, the author believes that no objections to such incentives should be made until their effect on organ donation can be studied. Peters suggests that "[o]rgan donation should be recognized as an act of societal participation in which the decedent, through the permission granted by surviving family members, renders a life-giving or lifesaving service to fellow Americans unknown to the donor or the family" and be honored with a death gratuity much like those paid to military 
reservists killed in the line of duty.

Phadke, Kishore D., and Anandh, Urmila. Ethics of Paid Organ Donation. Pediatric Nephrology 17 (5): 309-11, May 2002.

The authors discuss the pros and cons of payment for organ provision, and question whether ". . . regulatory law on [exploitative practices] is a possibility at all in a developing country such as India" where ". . . [v]igilance against wrong and unjust practices in relation to the existent laws is grossly inadequate" (p. 310). Believing that the "medical profession ... has a moral obligation to use its influence to change the cultural behavior of society, they posit that "... selling an organ may seem justifiable on the principle of autonomy . . . [but] should be considered as arising out of narcissism" ( $p$. 310). The article concludes with a plea to the medical community to give careful consideration to all aspects of incentives for procurement before legalizing trade in organs.

Radcliffe-Richards, Janet; Daar, Abdallah S.; Guttmann, Ronald D.; et al. [for the International Forum for Transplant Ethics]. The Case for Allowing Kidney Sales. Lancet 351 (9120): 1950-52, 27 June 1998.

Observing that "... the feelings of outrage and disgust that led to an outright ban on kidney sales ... have a force that seems to their possessors to need no further justification" (p. 1950), the authors call the typical arguments made against compensation for organ procurement ". . . attempts to justify the deep feelings of repugnance which are the real driving force of prohibition, and feelings of repugnance among the rich and healthy, no matter how strongly felt, cannot justify removing the only hope of the destitute and dying"(p. 1951). The authors stress that they are not arguing for an "unfettered market" in organs, but rather for reopening the discussion regarding compensation for organ procurement in the hope that ". . better arguments may yet be found" ( $p$. 1951).
Robeznieks, Andis. Strategies (not Financial)

for Organ Donors Explored. American Medical News 45 (39): 18, 21 October 2002.

Robeznieks describes recent grants made by the U.S. Department of Health and Human Services to study organ procurement issues and techniques and notes the concerns of several researchers who believe it is important to include studies of financial incentives if exemptions to the current law prohibiting such research can be obtained.

Ross, Lainie Friedman, and Woodle, E. Steve. Ethical Issues in Increasing Living Kidney Donations by Expanding Kidney Paired Exchange Programs. Transplantation 69 (8): 1539-43, 27 April 2000.

The authors review existing literature on kidney donation exchange programs, noting that many potential exchanges cannot take place due to incompatibility. In response, they suggest three alternatives: (1) altruistically unbalanced living donor-recipient exchanges in which one compatible pair exchanges organs with a second incompatible pair; (2) an indirect exchange between a living donor-recipient pair and a cadaveric donor-recipient pair on the basis of compatibility; and (3) an indirect exchange in which a living donation is made to a compatible stranger and the paired recipient of the living donor receives priority for the next compatible cadaveric organ. The authors observe that "[c] oncerns about coercion may be exacerbated by indirect exchanges because a reluctant or hesitant donor may no longer be able to invoke ABO incompatibility or a positive cross match as a convenient way to withdraw from consideration" and suggest including a comprehensive set of psychiatric and social work consultations to ensure that the living donor is truly "willing."

Rothman, David J. Ethical and Social Consequences of Selling a Kidney. JAMA 288 (13): 1640-41, 2 October 2002.

Commenting on the study of paid organ donation in India by Goyal et al. in the same 
issue, Rothman suggests that "[i]t is the availability of organs for purchase in some countries that allows other countries to forgo promoting and facilitating organ donation . . . [and] addressing their own cultural attitudes and practices that discourage donation" (p. 1641).

Rothman, David J.; Rose, Eric; Awaya, Tsuyoshi; et al. The Bellagio Task Force Report on Transplantation, Bodily Integrity, and the International Traffic in Organs. Transplantation Proceedings 29 (6): 2739-45, September 1997. Also available at: http://www.icrc.org/Web/eng/siteeng0.nsf/ iwpList302/87DC95FCA3C3D63EC1256B6600 5B3F6C.

Comprised of transplant surgeons, organ procurement specialists, human rights activists, and social scientists, the Task Force was convened to describe the issues involved in international organ procurement practices and to recommend ethical standards for addressing these issues. Sections of the report cover the sale of organs, the acquisition of organs from executed prisoners, and suspected criminal activities in organ procurement.

Sade, Robert M.; Kay, Nancy; Pitzer, Steve; et al. Increasing Organ Donation: A Successful New Concept. Transplantation 74 (8): 1142-46, 27 October 2002.

The authors describe a demonstration project of South Carolina's LifePoint organ procurement organization during which donation rates were substantially improved by increasing the number of procurement coordinators and by enhancing bereavement counseling.

Schwindt, Richard, and Vining, Aidan. Proposal for a Mutual Insurance Pool for Transplant Organs. Journal of Health Politics, Policy and Law 23 (5): 725-41, October 1998.

To avoid the monetary-based emphasis of futures-market proposals to increase organ donation, the authors describe a system in which "[a]n individual would receive priority for any needed transplant if that individual agrees that his or her organs will be available to other members of the insurance pool in the event of his or her death" (p. 727). They discuss the hazard of adverse selection (where high-risk individuals make up a greater proportion of the pool) and stress the benefits of the network aspect of such a system.

Siegel, Laurel R. Re-Engineering the Laws of Organ Transplantation. Emory Law Journal 49 (3): 917-55, Summer 2000.

After a review of federal and state laws on organ procurement, Siegel discusses the following proposals to increase the availability of organs: presumed consent, mandated choice, mutual insurance pool, markets for organs (futures and inter vivos), and death benefits.

Tax Incentives: A Market Solution to the Kidney Shortage? Hastings Center Report 11 (5): 3, October 1981.

On 3 June 1981, Representative Philip Crane (R-IL) introduced a bill to provide two types of tax incentives for cadaveric organ donation: a $\$ 25,000$ deduction for the donor's last taxable year, and a $\$ 25,000$ exclusion from estate taxes. Crane's bill also stipulated that the same tax incentives would apply if the organ donor were a dependent.

Tokarski, Cathy. Live Organ Donation: One Step Forward, Two Steps Back. Conference Report: Highlights From the National Committee for Quality Health Care's Conference On Organ Donation \& Transplantation: A Commitment to Quality, 21 November 2002, Washington, DC. Medscape Transplantation 3 (2), 2002. Posted 19 December 2002. 4 p. Available at: http://www.medscape. $\mathrm{com} /$ viewarticle/445640.

Reviewing what is known and what should be learned about live organ donation, the author includes a section on the "lack of clarity" in applying ethical directives for procuring cadaveric organs to evaluating donations from living donors. Noting that New York State Health Commissioner Antonia Novella 
recommended creating an independent donor advocate position after the death of a living donor at Mount Sinai Hospital, the conference report concludes with a call from Arthur Caplan for stewardship of living donors by the entire transplant community.

Ubel, Peter A.; Bryce, Cindy L.; Siminoff, Laura A.; Caplan, Arthur L.; and Arnold, Robert M. Pennsylvania's Voluntary Benefits Program: Evaluating an Innovative Proposal for Increasing Organ Donation. Health Affairs 19 (5): 206-11, September-October 2000.

The authors describe a proposed evaluation of Pennsylvania's Organ Donor Awareness Trust Fund. Established in 1994 by state legislation that allowed for a maximum reimbursement of $\$ 3,000$ to families of organ donors for funeral expenses, Pennsylvania's health secretary proposed in March 2000 that the money go for family expenses rather than funeral costs. At the time of publication, the trust fund was large enough to offer only $\$ 300$ to each family and its status vis-à-vis federal law remained "legally ambiguous" (p. 207).

United Network for Organ Sharing Ethics Committee. Financial Incentives for Organ Donation: A Report of the Payment Subcommittee. 30 June 1993. Available at: http://www.unos.org/Resources/bioethics.asp? index $=3$.

This report focuses on the use of financial incentives to increase cadaveric organ procurement. After a description of the various forms of financial incentives, the report presents the arguments for and against such incentives.

United States. Department of Health and Human Services. Health Resources and Services Administration (HRSA). Office of Special Programs. Division of Transplantation [and] United Network for Organ Sharing (UNOS) [and] University Renal Research and Education Association (URREA). 2001 Annual Report of the U.S. Organ Procurement and Transplantation Network and the Scientific
Registry for Transplant Recipients: Transplant Data 1991-2000. Rockville, MD: HRSA [and] Richmond, VA: UNOS [and] Ann Arbor, MI: URREA, 2001. 589 p. Available at: http://www.optn.org/data/annualReport.asp.

Volume I of this report contains a review of the data collection process and highlights of the statistics obtained. The data is presented in a tabular format, and covers such areas as cadaveric and living donor characteristics, cadaveric organ recovery and disposition, and completed transplants by type of organ.

United States. National Organ Transplant Act: Public Law 98-507. Enacted 19 October 1984. Statutes at Large 98: 2339-48.

Veatch, Robert M. Gift or Salvage: The Two Models of Organ Procurement. In his Transplantation Ethics, pp. 143-66. Washington, DC: Georgetown University Press, 2000.

Veatch discusses incentives for organ donation within the context of the utilitarian model of "routine salvaging" ("the common sense view that the body of the deceased . . . [is] no longer of any use to the dead person .... [or] the surviving family") versus the deontological "donation model" (". . . the moral notion that there is a duty to respect the bodily integrity of members of the moral community and that this obligation remains even after death") (p. 144), which he finds to have only one problem-"... it does not work" (p. 150) He reviews the ethics of various market approaches and incentives, including "rewarded gifting," describing them as either "unwelcome offers" or "irresistible offers." Veatch holds that an incentive is exploitative if it is made by someone who has ". .. the resources to and the responsibility for address[ing] the desperate one's problem in some other way" (p. 157) and notes that the United States has the resources to provide a welfare safety-net that, if implemented, would diminish the chances that payment for organ donation would be exploitative.

Wiggins, Ovetta. Pa. Organ Donors Get \$300 
Boost. Philadelphia Inquirer, 27 May 2002, A1. Available at: http://www.philly.com/mld/inquirer/ 3346239.htm.

After then-governor Robert Casey received a heart and liver from a slain youth whose family could not afford a funeral, Casey proposed that a trust fund for organ donors be established and that contributions be made through driver's license and tax form check-off options. Concerns about conflicts with federal law and exploitation of the disadvantaged prompted the Pennsylvania legislature to shift the focus of that proposal to living donors who now can receive a $\$ 300$ benefit for meals and lodging when they donate.

Wight, C.; Cohen, B.; Beasley, C.; Miranda, B.; and Deblander, G. Donor Action: A Systematic Approach to Organ Donation. Transplantation Proceedings 30 (5): 2253-54, August 1998.

Donor Action, an international initiative to alleviate the shortage of organs for transplantation, is a collaborative effort of three organizations: the Eurotransplant Foundation (Netherlands), the Organizacion Nacional de Trasplantes (Spain), and the Partnership for Organ Donation (United States). Pooling their expertise, the partners provide data collection tools for hospitals to review their current organ retrieval practices, a software package to analyze the data obtained from their reviews, and education modules to address problems identified in the donation process. The authors discuss pilot studies using these evaluation tools at 11 hospitals in the Netherlands, Spain, the United Kingdom, and Canada. Updates on this initiative can be found on the Donor Action web site at: http://www.donoraction.org/.

Patricia Milmoe McCarrick, M.L.S., recently retired after 17 years as a Reference Librarian, National Reference Center for Bioethics Literature, Georgetown University, Washington, DC.

Martina Darragh, M.L.S., is a Reference Librarian, National Reference Center for Bioethics Literature, Georgetown University, Washington, DC.

Produced at the National Reference Center for Bioethics Literature, Kennedy Institute of Ethics, Georgetown University, Box 571212, Washington, DC 20057-1212. The Center operates on a contract with the National Library of Medicine, National Institutes of Health. Additional support is provided by the National Center for Human Genome Research, National Institutes of Health, and by other public and private sources. 